\title{
Effectiveness of magnesium source and rate in the fertilization of banana grown on an Ultisol in Puerto Rico ${ }^{1,2}$
}

\author{
Héber Irizarry ${ }^{3}$, Ricardo Goenaga ${ }^{4}$ and Ulises Chardón ${ }^{5}$
}

J. Agric. Univ. P. R. 84(1-2):35-45 (2000)

\begin{abstract}
A 33-month study was conducted to determine the response of banana grown on a clayey, mixed isohyperthermic Aquic Haplohumults to four sources and five rates of magnesium. The sources of $\mathrm{Mg}$ were dolomitic limestone $(10.4 \% \mathrm{Mg}$ ), magnesium oxide (Fert-O-Mag, $51.5 \% \mathrm{Mg}$ ), and magnesium sulfate (Granusol, $45.0 \% \mathrm{Mg}$; Kieserite, $17.5 \% \mathrm{Mg}$ ). The $\mathrm{Mg}$ rates were $0,45,90,135$ and $180 \mathrm{~kg} / \mathrm{ha} / \mathrm{crop}$. We obtained data of marketable bunch weight, $\mathrm{Mg}$ concentration in the third youngest leaf and the exchangeable Mg at two soil depths for two ratoon crops, R1 and R2. Results showed that sources of $\mathrm{Mg}$ had no significant effect on the three attributes studied. The rate $\times$ ratoon crop interaction, however, was highly significant $(P \leq 0.01)$ for bunch weight, leaf $\mathrm{Mg}$ concentration and the soil exchangeable $\mathrm{Mg}$. Bunch weight, leaf $\mathrm{Mg}$ concentration and soil exchangeable $\mathrm{Mg}$ increased linearly with the amount of $\mathrm{Mg}$ applied in the first and second ratoons (R1 and R2). The highest bunch weight $(28.4 \mathrm{~kg})$ and the highest leaf Mg concentration $(2 \mathrm{~g} / \mathrm{kg}$ ) were obtained with the application of $180 \mathrm{~kg} / \mathrm{ha}$ in R2. This leaf $\mathrm{Mg}$ concentration, however, was considered sub-optimal for banana plants approaching the flowering stage and grown on highly weathered soils. The highest application rate of $180 \mathrm{~kg} / \mathrm{ha}$ also increased the soil exchangeable $\mathrm{Mg}$ to its highest level of $1.6 \mathrm{cmol}(+) / \mathrm{kg}$ in $\mathrm{R} 1$ at a soil depth of 0 to $20 \mathrm{~cm}$. Leaching and nutrient imbalance were factors that limited $\mathrm{Mg}$ availability. Although the banana response to $\mathrm{Mg}$ fertilization was linear, it was concluded that any further increase above the existing recommended rate of $55 \mathrm{~kg} / \mathrm{ha} / \mathrm{year}$ would increase production costs considerably unless a cheaper source of $\mathrm{Mg}$ is used.
\end{abstract}

Key words: Banana, fertilization, magnesium salt, leaching, weathered soil

RESUMEN

Efectividad de fuentes y cantidades de magnesio en la fertilización del guineo sembrado en un suelo Ultisol de Puerto Rico

'Manuscript submitted to Editorial Board 23 April 1999.

2This paper covers work carried out cooperatively between the Agricultural Research Service-USDA and the Agricultural Experiment Station, University of Puerto Rico. The authors are grateful to Nicolás Díaz and Javier Fuentes, Agricultural Research Technicians, for their assistance in carrying out the experiment.

${ }^{3}$ Research Horticulturist, Tropical Agriculture Research Station, 2200 Pedro Albizu Campos Ave., Suite 201, Mayagüez, P.R. 00680-5470.

${ }^{4}$ Research Plant Physiologist, Tropical Agriculture Research Station, Mayagüez, P.R.

'Chemist, Tropical Agriculture Research Station, Mayagüez, P.R. 
Se determinó la respuesta del guineo, sembrado en un suelo altamente meteorizado, a cuatro fuentes y cinco cantidades de magnesio durante un periodo de 33 meses. Las fuentes de $\mathrm{Mg}$ fueron dolomita-calcitica $(10.4 \%$ $\mathrm{Mg}$ ), óxido de magnesio (Fert-0-Mag, $51.5 \% \mathrm{Mg}$ ) y sulfato de Mg (Granusol, $45.0 \% \mathrm{Mg}$; Kieserite, $17.5 \% \mathrm{Mg}$ ). Las cantidades de $\mathrm{Mg}$ aplicadas fueron 0 , $45,90,135$ y $180 \mathrm{~kg} / \mathrm{ha} / \mathrm{cosech}$. Se recopilaron datos de peso mercadeable del racimo, concentración de $\mathrm{Mg}$ en la tercera hoja más joven de las plantas y el $\mathrm{Mg}$ intercambiable a dos profundidades en el suelo para dos cosechas, R1 y R2. Los resultados demostraron que las fuentes de $\mathrm{Mg}$ no tuvieron efectos significativos sobre los tres atributos observados. Las cantidades de $\mathrm{Mg}$ aplicadas afectaron significativamente el peso del racimo, la concentración del nutrimento en la hoja y el $\mathrm{Mg}$ intercambiable pero la magnitud del efecto dependió de la cosecha. El peso mayor del racimo $(28.4 \mathrm{~kg})$ y la concentración más alta de $\mathrm{Mg}$ en la hoja $(2 \mathrm{~g} / \mathrm{kg}$ ) se obtuvieron con la aplicación de $180 \mathrm{~kg} / \mathrm{ha}$ de $\mathrm{Mg}$ en la cosecha R2. Sin embargo, la concentración de $2 \mathrm{~g} / \mathrm{kg}$ de $\mathrm{Mg}$ en la hoja es considerada baja para la planta de guineo próxima a la floración y sembrada en un suelo altamente meteorizado. La aplicación de $180 \mathrm{~kg} / \mathrm{ha}$ de $\mathrm{Mg}$ también aumentó el $\mathrm{Mg}$ intercambiable en el suelo al nivel más alto de $1.6 \mathrm{cmol}(+) / \mathrm{kg}$ en la cosecha $R 1$ y a la profundidad de 0 a $20 \mathrm{~cm}$. La lixiviación y el desbalance nutricional fueron factores que afectaron la disponibilidad de magnesio. Aunque la respuesta del guineo a la fertilización con $\mathrm{Mg}$ fue lineal, se concluyó que un aumento sobre la reco-

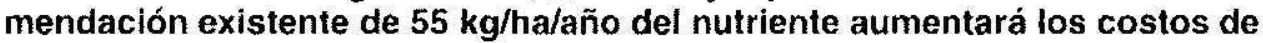
producción considerablemente a menos que se utilice una fuente más barata de magnesio.

\section{INTRODUCTION}

Banana and plantain (Musa spp.) are extensively cultivated in the tropics on highly weathered Ultisols and Oxisols. These soils are characterized by their low natural fertility, mainly in respect to $\mathrm{P}, \mathrm{K}, \mathrm{Ca}$ and $\mathrm{Mg}$, and the presence of potentially toxic levels of $\mathrm{Al}$ and $\mathrm{Mn}$ (Sánchez, 1976). Even with these constraints, traditional crops can produce economic yields if these soils are properly managed.

A magnesium concentration of $3 \mathrm{~g} / \mathrm{kg}$ in the lamina of the third youngest leaf of 7-month-old banana plants grown on an Ultisol has been considered near-optimum, and applying $\mathrm{Mg}$ fertilizer when foliar levels are below this concentration has been found to increase yields (Trizarry et al., 1988; 1990). A typical Mg-deficiency symptom in young banana plants grown on highly weathered soils is the presence of a pale-yellow streak extending from near the leaf-lamina margin toward the mid-rib in older leaves. We have also observed that after flowering, Mg-deficient banana plants attain leaf senescence at a faster pace, thus affecting fruit filling and consequently yield.

Magnesium uptake in banana grown on a typical Ultisol has been determined to be $55 \mathrm{~kg} / \mathrm{ha} / \mathrm{crop}$ (Irizarry et al., 1988). However, banana planted on a similar soil type for three successive years responded to the application of $275 \mathrm{~kg} / \mathrm{ha} /$ year of $\mathrm{Mg}$ from dolomitic limestone the first year and magnesium oxide (Fert-O-Mag) in subsequent years 
(Irizarry et al., 1990). Likewise, in this study the optimum economic application rate of $\mathrm{Mg}$ was found to be between 112 to $168 \mathrm{~kg} / \mathrm{ha} /$ year. Since the Mg-supplying power of some of the local upland Ultisols may be as low as $35 \mathrm{~kg} / \mathrm{ha} /$ year (Vicente-Chandler et al., 1974), about $55 \mathrm{~kg} /$ ha/year of $\mathrm{Mg}$ is recommended to supplement the N-P-K fertilization in banana grown on highly weathered soils (Agric. Exp. Sta., 1995).

Magnesium uptake from the soil may depend on the plant root surface area, the soil cation exchange capacity, and the competition and/or concentration of other cations in the soil solution (Ritchey and Irizarry, 1993). Since highly weathered soils are usually intensively limed, "Mgfixation," caused by the coprecipitation of $\mathrm{Mg}$ with Al upon liming, may play a major role in limiting the availability of $\mathrm{Mg}$ in crops grown on these soils (Myers et al., 1988; Martínez et al., 1994; 1996). Low Mg uptake in banana grown on Ultisols and Oxisols is worsened by the high potassium requirement of the crop (Irizarry et al., 1988), and the antagonistic effect between $\mathrm{K}$ and $\mathrm{Mg}$ (Lahav, 1974; Murray, 1960; Soto, 1985).

The most commonly used sources of $\mathrm{Mg}$-fertilizer are magnesium sulfate (Epsom salts and Kieserite), magnesium oxide (Fert-O-Mag) and potassium-magnesium sulfate (Sul-Po-Mag).

This study was undertaken to determine the effect of sources and rates of commercial $\mathrm{Mg}$-supplying fertilizers in banana grown on a highly weathered soil, and to trace the vertical and lateral movement of $\mathrm{Mg}$ in the soil profile.

\section{MATERLALS AND METHODS}

An experiment was conducted between November 1993 and July 1996 at the Corozal Agricultural Research Station of the University of Puerto Rico. The site is located in the north-central humid region $\left(18^{\circ} 20^{\prime} \mathrm{N}, 66^{\circ} 18^{\prime} \mathrm{E}\right.$; elevation $\left.195 \mathrm{~m}\right)$. The mean monthly minimum and maximum temperatures during the experimental period were 19.4 and $30.5^{\circ} \mathrm{C}$, respectively. Mean annual rainfall was $1,645 \mathrm{~mm}$; Class A pan evaporation, $1,448 \mathrm{~mm}$. The experiment was conducted under rain fed conditions, and moisture deficits occurred during the months of February, March, April, June, July and December.

The soil is a typical Ultisol (clayey, mixed isohyperthermic Aquic Haplohumults). Relevant chemical properties in the top $20-\mathrm{cm}$ soil layer were $\mathrm{pH}, 4.8$; extractable $\mathrm{P}, 3.7 \mathrm{mg} / \mathrm{kg}$ (Bray method 2); and 0.6, $5.4,0.4$ and $1.4 \mathrm{cmol}(+) / \mathrm{kg}$ of exchangeable $\mathrm{K}, \mathrm{Ca}, \mathrm{Mg}$ and $\mathrm{Al}$, respectively.

Corms of the Grand Nain (Musa AAA) cultivar weighing about $2 \mathrm{~kg}$ were planted 1.8 by $2.4 \mathrm{~m}$ apart at about 2,240 plants per hectare. Each plot consisted of four experimental plants surrounded by guard rows 
and ditches to prevent the overlapping of fertilizer treatment effects. At planting, plants were fertilized with $11 \mathrm{~g}$ of $\mathrm{P}$ as triple superphosphate placed under the propagating corms.

Four sources of $\mathrm{Mg}$ and five application rates were arranged in a randomized complete block design with six replications. The sources were dolomitic limestone (10.4\% Mg), magnesium oxide (Fert-O-Mag, 51.5\% $\mathrm{Mg}$ ) and magnesium sulfate (Granusol, $45.0 \% \mathrm{Mg}$; Kieserite, $17.5 \% \mathrm{Mg}$ ). Both Fert-O-Mag and Granusol are products manufactured by American Minerals, P.O. Box 2005, Dunedin, FL 34697. Kieserite is manufactured by Kali und Salz-Agricultural Advisory Department, P.O. Box 102029.34111 Kassel, Germany, and the dolomitic limestone was obtained from Ochoa Fertilizer Co., Inc., P.O. Box 363128, San Juan, PR 00936-3128. ${ }^{6}$ The five rates of $\mathrm{Mg}$ were $0,45,90,135$ and $180 \mathrm{~kg} / \mathrm{ha} / \mathrm{crop}$. Fert-O-Mag and Granusol were mixed and applied with a $10-2-30\left(\mathrm{~N}, \mathrm{P}_{2}\right.$ $\mathrm{O}_{5}, \mathrm{~K}_{2} \mathrm{O}$ ) fertilizer. The complete fertilizer, without $\mathrm{Mg}$ and with the $\mathrm{Mg}$ supplements, was applied at the rate of about $635 \mathrm{~kg} / \mathrm{ha} /$ application three months after planting and every three months thereafter. The Kieserite and an additional treatment of Granusol were applied alone between the complete fertilizer applications. The fertilizer was applied in a circular band about $15 \mathrm{~cm}$ from the base of the plants. In the dolomitic limestone treatments the total $\mathrm{Mg}$ that corresponded to a 33month cropping was incorporated into the top $20-\mathrm{cm}$ soil layer before planting. The addition of about $5,170 \mathrm{~kg} / \mathrm{ha}$ of dolomitic limestone to supply the $\mathrm{Mg}$ needed at the maximum rate increased the soil $\mathrm{pH}$ to 5.3. Therefore, the soil $\mathrm{pH}$ in other treatments was adjusted to near the same level with the incorporation of ground calcium carbonate. No additional liming was necessary because local Ultisols and Oxisols contain essentially no exchangeable $\mathrm{Al}$ above a pH of 5.0 (Abruña et al., 1970). Weeds, nematodes, the corm weevil, and yellow Sigatoka were controlled by following published recommendations (Agric. Exp. Sta., 1995).

A desuckering program was implemented about four months after planting to maintain the mother plant and two ratoon suckers in each stump. All plant residues generated by this and other agronomic practices were removed from the plots. Leaf tissue and soil samples were taken before the complete fertilizer applications about $6,9,12,15,24$ and 27 months after planting. In each plot, tissue from the middle of the lamina of the third youngest leaf of four plants was composited, oven-dried, and ground to pass through a 20 -mesh screen. Levels of $K$,

\footnotetext{
"Trade names in this publication are used only to provide specific information. Mention of a trade name or manufacturer does not constitute a warranty of equipment or materials by the USDA-ARS or the Agricultural Experiment Station of the University of Puerto Rico, nor is this mention a statement of preference over other equipment or materials.
} 
$\mathrm{Ca}$ and $\mathrm{Mg}$ were determined by the dry-ashing method and atomic absorption spectroscopy. One soil core was taken on the fertilizer band of each experimental plant, and three additional cores were obtained about $1 \mathrm{~m}$ away from the plants toward the middle of the plot at 0 to 20 - and 20 to $40-\mathrm{cm}$ soil depths. The samples taken from the plant's fertilizer band and those taken from the middle of the plot were composited separately, air-dried, ground, sieved through a 10-mesh screen and analyzed for $\mathrm{pH}, \mathrm{P}, \mathrm{K}, \mathrm{Ca}, \mathrm{Mg}$, and $\mathrm{Al}$. Soil reaction was measured with an epoxy combined electrode $\mathrm{pH}$ meter using a 1:2 soilto-water ratio. Phosphorus was extracted by using Bray method 2 and determined colorimetrically; $\mathrm{K}, \mathrm{Ca}$ and $\mathrm{Mg}$ were extracted with neutral $1 \mathrm{M} \mathrm{NH} \mathrm{NH}_{4} \mathrm{OAC}$, and the exchangeable $\mathrm{Al}$ with $1 \mathrm{~N} \mathrm{KCl}$. All cations were determined by atomic absorption spectroscopy.

The vertical movement of the $\mathrm{Mg}$ applied on the fertilizer band was determined by subtracting from the various sources and rates the amount of $\mathrm{Mg}$ present in the $0 \mathrm{Mg}$ treatment at 0 to 20- and 20 to 40 $\mathrm{cm}$ soil depths. The difference detected at the 20 to $40-\mathrm{cm}$ soil depths was considered leached $\mathrm{Mg}$ from the surface application. Lateral movement of $\mathrm{Mg}$ was estimated in a similar manner, but using the soil sample data obtained in the middle of the plots at the two soil depths.

Two weeks after flowering, the false hand and the male floral bud were removed from the immature bunch, which was immediately covered with a polyethylene bag. Bunches were harvested about 112 days after flowering. The bunch marketable weight (bunch weight minus rachis weight), and leaf tissue and soil sample data obtained from two ratoon crops were statistically analyzed by using the ANOVA procedure, and regression analysis (SAS, 1987). Only coefficients significant at $\mathrm{P} \leq 0.01$ were retained in the model.

\section{RESULTS AND DISCUSSION}

The plant crop was seriously affected by dry weather conditions from December 1993 through September 1994. During this period, the evaporation was twice the amount of rainfall recorded, 1,382 and $682 \mathrm{~mm}$, respectively. Since this dry condition caused some abortion of bunches, data for the plant crop were discarded. Therefore, the results and discussion presented herein include only two ratoon crops, $R 1$ and $R 2$.

There was no significant effect of source of $\mathrm{Mg}$, source $\times$ rate and source $\times$ ratoon crop interactions on marketable bunch weight, leaf $\mathrm{Mg}$ concentration or soil exchangeable $\mathrm{Mg}$ (analysis of variance not shown). Rate of $\mathrm{Mg}$ and rate $\times$ ratoon crop interaction were highly significant $(\mathrm{P} \leq 0.01)$ for the bunch, plant, and soil attributes studied. Therefore, results are reported for each $\mathrm{Mg}$ rate-crop combination. 
Marketable bunch weight was linearly related to the amount of $\mathrm{Mg}$ applied in each ratoon crop (Figure 1a). The greatest response to applied $\mathrm{Mg}$ was obtained in the R2 crop, which produced bunches weighing $28.4 \mathrm{~kg}$ when fertilized with $180 \mathrm{~kg} / \mathrm{ha}$. This rate, however, increased bunch weight to only $21.8 \mathrm{~kg}$ in R1. As compared to the $0 \mathrm{Mg}$ treatment, the application of $180 \mathrm{~kg} / \mathrm{ha} / \mathrm{crop}$ of $\mathrm{Mg}$ resulted in a bunch weight increase of $16.3 \%$ in $\mathrm{R} 1$ and $12.3 \%$ in R2. Overall, bunch weight increase for each rate of $\mathrm{Mg}$ in $\mathrm{R} 2$ was about $25 \%$ higher than in $\mathrm{R} 1$. However, other factors such as the tendency of the banana plant to produce heavier bunches in older ratoons and changes in rainfall patterns may also have influenced the increase in yield obtained in R2.

The plant tissue and soil sampling data that represent RI and R2 were obtained 15 and 27 months after planting, respectively. At that time the ratoon plants were about two months away from reaching the flowering peak.

Leaf $\mathrm{Mg}$ concentration significantly increased with increments in rates of $\mathrm{Mg}$ in both ratoon crops (Figure $1 \mathrm{~b}$ ), reaching approximately 2 $\mathrm{g} / \mathrm{kg}$ in the $\mathrm{R} 2$ crop when fertilized with $180 \mathrm{~kg} / \mathrm{ha}$ of $\mathrm{Mg}$. However, a $\mathrm{Mg}$ concentration of $2 \mathrm{~g} / \mathrm{kg}$ has been reported to be sub-optimal for commercial banana production (Soto, 1985). A 7-month-old banana plant grown on highly weathered Ultisols and Oxisols is considered well nourished if the $\mathrm{Mg}$ content in the third uppermost leaf is about $3 \mathrm{~g} / \mathrm{kg}$ (Irizarry et al., 1988). We would have needed to apply in the R2 crop about $375 \mathrm{~kg} / \mathrm{ha}$ of $\mathrm{Mg}$ to attain in the leaf the recommended concentration of $3 \mathrm{~g} / \mathrm{kg}$. This rate would have theoretically increased bunch weight to $32.2 \mathrm{~kg}$. The current commercial source of $\mathrm{Mg}$ used by local fertilizer companies is Gramag $(45.0 \% \mathrm{Mg})$, the sale price of which is about $\$ 634.50$ per $1,000 \mathrm{~kg}$ or $\$ 1.41$ per $1 \mathrm{~kg}$ of $\mathrm{Mg}$. Therefore, it costs the growers about $\$ 77.55$ to apply the recommended rate of $55 \mathrm{~kg} / \mathrm{ha} /$ year to banana grown on highly weathered soils. If the recommended $\mathrm{Mg}$ rate is plotted in the graph of Figure $1 \mathrm{a}$, the expected bunch weight is 19.3 and $26.0 \mathrm{~kg}$ for $\mathrm{R} 1$ and $\mathrm{R} 2$, respectively. Before hurricane "Georges," the farm gate price for high quality banana fruit averaged $\$ 7.00$ per box of $18.1 \mathrm{~kg}$. On the basis of this economic analysis, we concluded that any further increase in $\mathrm{Mg}$ fertilization above the existing recommended rate of $55 \mathrm{~kg} / \mathrm{ha} /$ year would increase production costs considerably unless a cheaper source of $\mathrm{Mg}$ is found. There are deposits of $\mathrm{Mg}$-bearing carbamate rocks in Puerto Rico containing dolomiticlimestone with up to $11.2 \% \mathrm{Mg}$ (Vázquez et al., 1957). This product could be intensively used as a slow release cheaper $\mathrm{Mg}$ source for liming highly weathered soils.

Increments in rates of $\mathrm{Mg}$ from 0 to $180 \mathrm{~kg} / \mathrm{ha}$ significantly increased the exchangeable $\mathrm{Mg}$ at two soil depths in each ratoon crop 

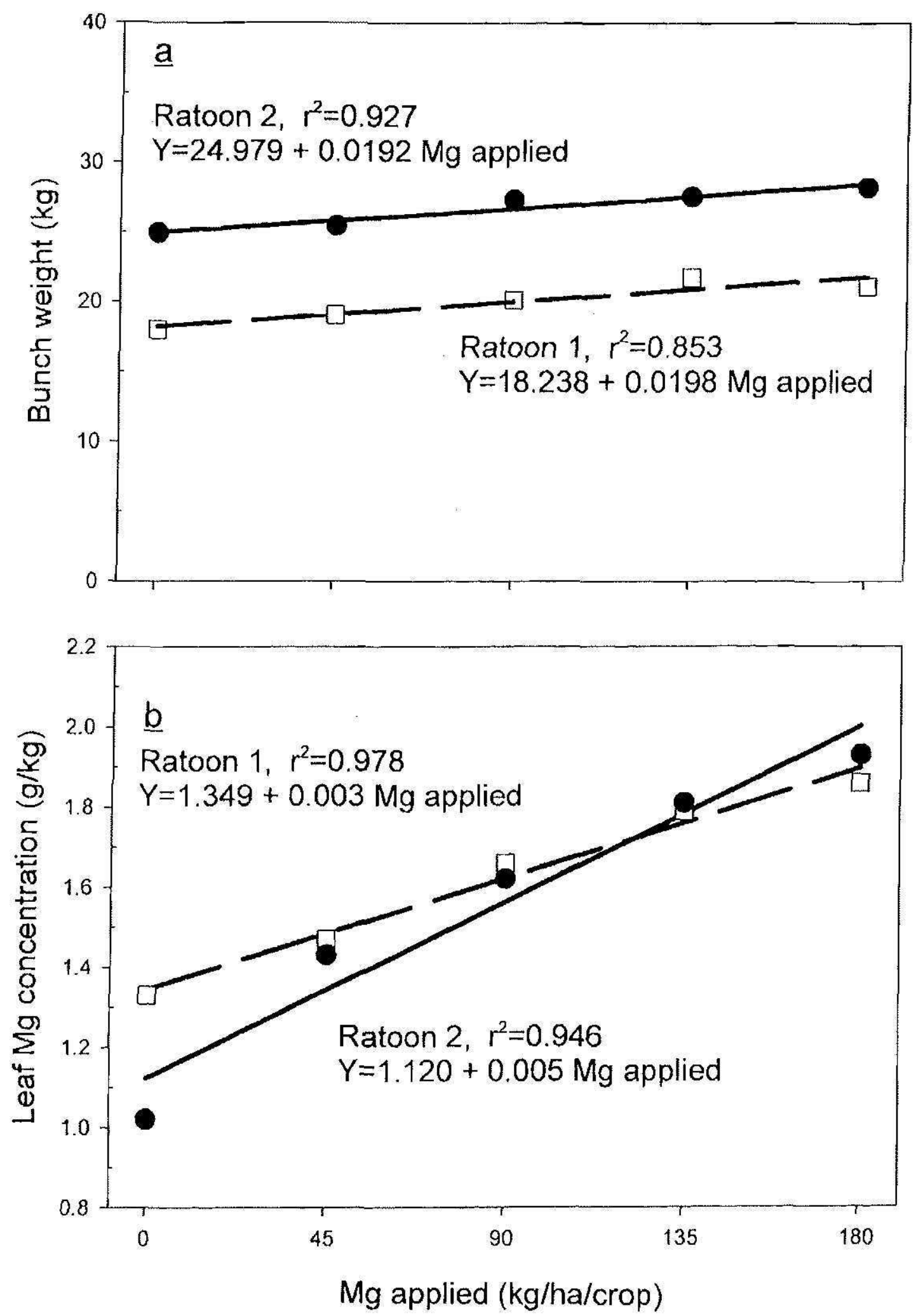

FIGURE 1. Bunch weight (a) and leaf magnesium concentration (b) in two banana ratoons (R1 and R2) grown on an Ultisol fertilized with five rates of magnesium. 
(Figure 2). In the $\mathrm{R} 1 \mathrm{crop}$ the rate of $180 \mathrm{~kg} / \mathrm{ha}$ increased the exchangeable $\mathrm{Mg}$ from $0.5 \mathrm{cmol}(+) / \mathrm{kg}$ with $0 \mathrm{Mg}$ to the maximum of $1.6 \mathrm{cmol}(+) /$ $\mathrm{kg}$ at a soil depth of 0 to $20 \mathrm{~cm}$. This treatment increased the exchangeable $\mathrm{Mg}$ to $1.0 \mathrm{cmol}(+) / \mathrm{kg}$ at the lower soil depth of 20 to $40 \mathrm{~cm}$. The high amount of exchangeable $\mathrm{Mg}$ detected in $\mathrm{R} 1$ at both soil depths may be caused by residual soil $\mathrm{Mg}$ from fertilizer not used by the plant crop, which was discarded and pruned before harvest because of a severe drought. In the $\mathrm{R} 2$ crop the highest rate increased the exchangeable $\mathrm{Mg}$ to $1.2 \mathrm{cmol}(+) / \mathrm{kg}$ at the $0-$ to $20-\mathrm{cm}$ depth and to $0.6 \mathrm{cmol}(+) / \mathrm{kg}$ at the lower depth. Regardless of the soil depth, the greatest increase in exchangeable $\mathrm{Mg}$ was obtained in $\mathrm{R} 1$ crop at all rates. However, the presence of a higher amount of exchangeable $\mathrm{Mg}$ failed to increase the bunch weight and leaf $\mathrm{Mg}$ concentration in Rl plants (Figures 1a, 1b).

Leaching of $\mathrm{Mg}$ below the $20 \mathrm{-cm}$ soil depth was related to the rates of $\mathrm{Mg}$ applied in both ratoon crops (Figure 2). With the application of the highest rate, about 33 and $25 \%$ of the exchangeable $\mathrm{Mg}$ in excess of the 0 rate was located below the 20 -cm soil depth in $R 1$ and $R 2$, respectively. Leaching has been identified as a major cause of nutrient losses, particularly in soil with low cation exchangeable capacity (Godefroy et al., 1975). Banana, like plantain, has a shallow root system concentrating most of its roots in the top $20 \mathrm{~cm}$ of soil (Summerville, 1939; Irizarry et al., 1981). Although the experiment was planted on a $20 \%$ slope, there was no evidence of $\mathrm{Mg}$ surface runoff or underground lateral movement. The exchangeable $\mathrm{Mg}$ detected in the soil samples taken in the middle of the Mg-fertilized plots was always similar to or somewhat lower than the values obtained from the $0 \mathrm{Mg}$ plots at both soil depths (data not shown). This finding may be explained by the limited run-off allowed with the digging of ditches $4.9 \mathrm{~m}$ apart against the slope.

Increments in $\mathrm{Mg}$ rates significantly reduced the $\mathrm{K} / \mathrm{Mg}$ and $\mathrm{Ca} / \mathrm{Mg}$ ratios in both ratoon crops at the two soil depths (Figure 3). However, the maximum rate of $180 \mathrm{~kg} / \mathrm{ha} / \mathrm{crop}$ was not sufficient to reduce these ratios to acceptable levels. Soils for banana production are considered well balanced if $\mathrm{K} / \mathrm{Mg}$ ratios are between 0.2 and 0.5 (García et al., 1978). Higher ratios are associated with nutrient imbalance and a $\mathrm{Mg}$ deficiency in plants. A Ca/Mg ratio in the range of 3.4 to 4.0 was considered satisfactory for intensive banana production in Costa Rica (López, 1983). The high $\mathrm{K} / \mathrm{Mg}$ ratios obtained in our experiment were probably influenced by the amount of $\mathrm{K}$ applied as fertilizer, about $527 \mathrm{~kg} / \mathrm{ha} /$ crop. However, a banana crop grown on highly weathered soils demands high quantities of $\mathrm{K}$, about $710 \mathrm{~kg} / \mathrm{ha} / \mathrm{crop}$, about $37 \%$ of which is removed from the field at harvest (Irizarry et al., 1988).

Because of the intensive nitrogen fertilization with a residual acid compound such as ammonium sulfate, the initial soil $\mathrm{pH}$ in the fertil- 


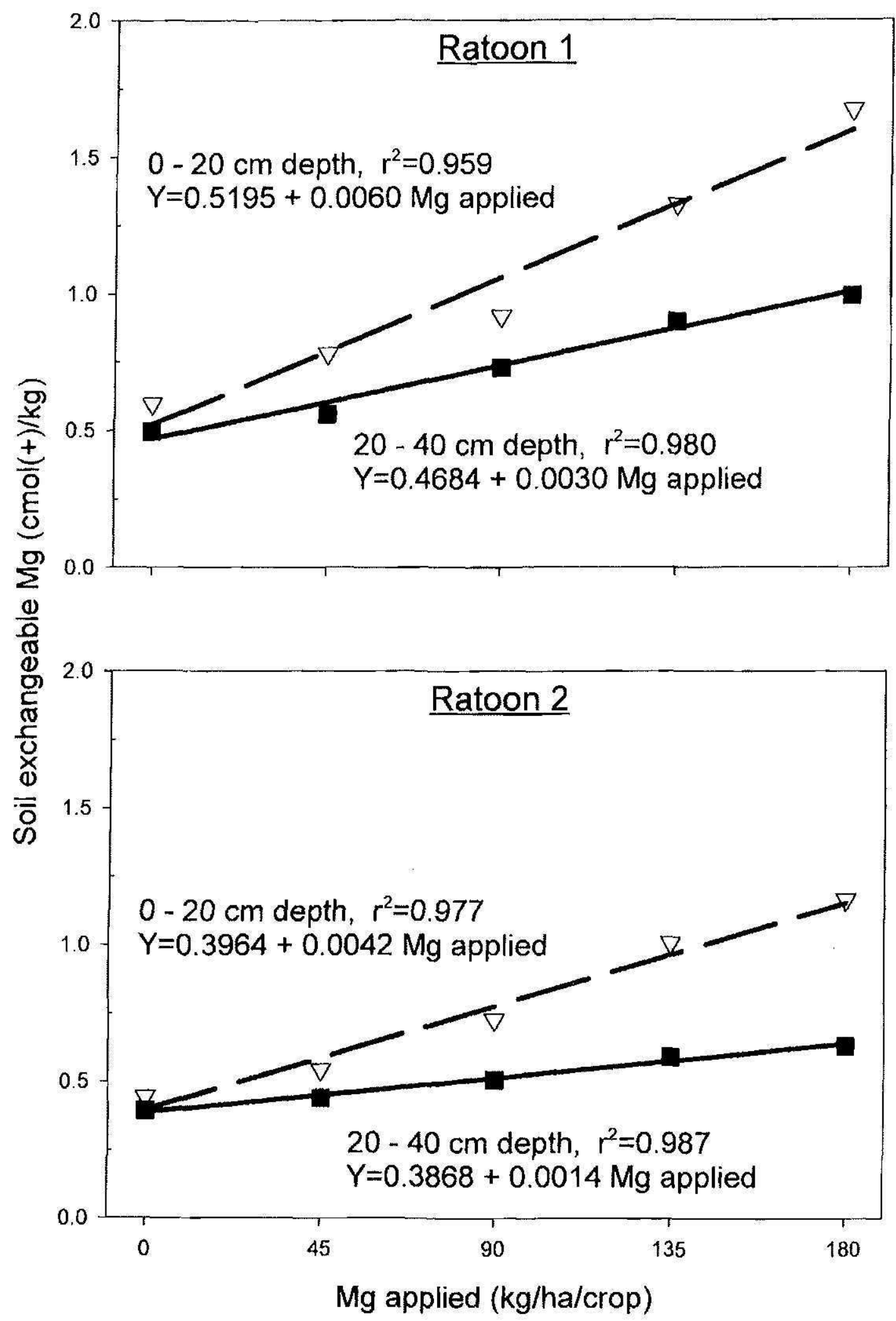

FIGURE 2. Relationship between the exchangeable magnesium at two soil depths in banana ratoons ( $R 1$ and $R 2$ ) grown on an Ultisol fertilized with five rates of magnesium. 

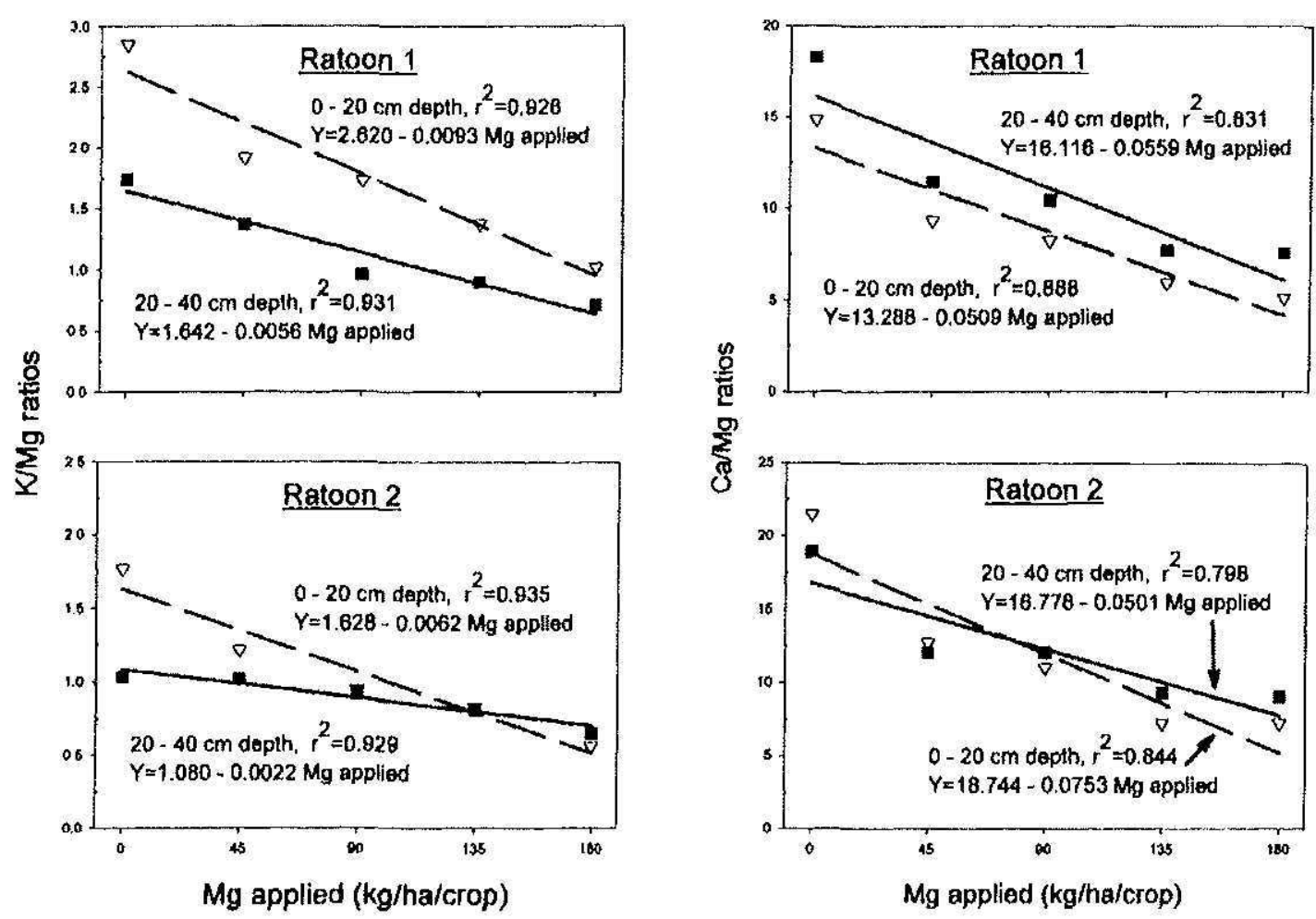

Figure 3. Relationship between the $\mathrm{K} / \mathrm{Mg}$ and $\mathrm{Ca} / \mathrm{Mg}$ ratios at two soil depths in banana ratoons ( $R 1$ and $R 2$ ) grown on an Ultisol fertilized with five rates of magnesium.

izer band was reduced from 5.3 to as low as 4.7 at a soil depth of 0 to $20 \mathrm{~cm}$, and to 4.5 at a depth of 20 to $40 \mathrm{~cm}$ in both ratoon crops. However, $\mathrm{Al}$ saturation in $\mathrm{R} 1$ and $\mathrm{R} 2$ plots averaged only $10.5 \%$ at a soil depth of 0 to $20 \mathrm{~cm}$, and $25.3 \%$ below the $20-\mathrm{cm}$ depth. Therefore, in this experiment we did not consider that "Mg fixation" (Myers et al., 1988; Martínez et al., 1994; 1996) played a major role in the availability of $\mathrm{Mg}$ to the crop.

\section{LITERATURE CITED}

Abruña, F., J. Vicente-Chandler, R. W. Pearson and S. Silva, 1970. Crop response to soil acidity factors in Ultisols and Oxisols. I-Tobacco. Soil Sci. Soc. Amer: Proc. 34:629. 635.

Agric. Exp. Sta., 1995. Conjunto Tecnológico para la producción de plátanos y guineos. Univ. P.R., Río Piedras, P.R. Publ. 97.

García, V., E. Fernández-Caldas, C. E. Alvarez and J. Robles, 1978. Desequilibrios potásico-magnésicos en los cultivos de plátano de Tenerife. Fruits 33:7-13.

Godefroy, J, E. J. Roose and M. Muller, 1975. Estimation des pertes par les eaux de ruisselement et de drainage de elements fertilisants dans un sol de bananeraie du sud de la Côte d'lvoire. Fruits 30: 223-235.

Irizarry, H., J. Vicente-Chandler and S. Silva, 1981. Root distribution of plantains growing on five soil types. J. Agric. Univ. P.R. 65(1):29-34. 
Irizarry, H., E. Rivera and J. Rodríguez, 1988. Nutrient uptake and dry matter composition in the plant crop and first ratoon of the Grand Naine banana gxown on an Ultisol. J. Agric. Univ.P. R. 72:337-351.

Irizarry, H., E. Rivera and J. Rodriguez, 1990. Response of bananas (Musa acuminata, AAA) to magnesium fertilization in an Ultisol. . Agric. Univ. P.R. 74:419-426.

Lahav, E., 1974. The influence of potassium on the content of macroelements in the banana sucker: Agrochimica 28(1-2):194-203.

López, C., 1983. Diagnóstico del estado nutricional de plantaciones bananeras en Costa Rica. ASBANA 6(19):13-18.

Martínez, G. A., L. Peña-Córdova and L. A. Figueroa, 1994. A thermodynamic evaluation of the addition of calcium and magnesium to an Ultisol: $\mathrm{I}-\mathrm{Ca}(\mathrm{OH})_{2}$ addition. $J$. Agric. Univ P.R. 78:99-110.

Martínez, G. A., L. Peña-Córdova and L. A. Figueroa, 1996. A thermodynamic evaluation of the addition of calcium and magnesium to an Ultisol: $\mathrm{II}-\mathrm{Ca} \mathrm{SO}_{4}$ addition. $J$. Agric. Univ. P.R. 80:1-12.

Murray, D. B., 1960. The effect of deficiencies of the major nutrients on growth and leaf analysis of the banana. Trop. Agric. 37(2):97-106.

Myers, J. A., E. O. McLean and J. M. Bigham, 1988. Reductions in exchangeable magnesium with liming of acid Ohio soils. Soil Sci. Soc. Am. J. 52:131-136.

Ritchey, K. D. and H. Irizarry, 1993. Leaching of Mg fertilizers in Puerto Rican Ultisols. J. Agric. Univ. P.R. 77:167-180.

Sánchez, P. A., 1976. Properties and management of soils in the tropics, John Wiley and Sons Inc., NY.

SAS Institute, 1987. SAS/STAT: Guide for personal computers. Ver'sion 6. Cary, NC.

Soto, M., 1985. Bananos: Cultivo y comercialización. Litografía e Imprenta LIL S.A., Tibas, Costa Rica.

Summerville, W. A. T., 1939. Root distribution of the banana. Queen. Agric. J. 52:376-392.

Vázquez, L., O. Méndez and R. Padró, 1957. Preliminary report on calcitic dolomite of northern Puerto Rico. Economic Development Administration, Bull. 5, San Juan, PR.

Vicente-Chandler, J., F. Abruña, R. Caro-Costas, J. Figarella, S. Silva and R. W. Pearson, 1974. Intensive grassland management in the humid tropics of Puerto Rico. Agric. Exp. Sta., Univ. P.R. Bull 233. 